\title{
Nutrient Use Pattern of Diospyros Melanoxylon in Comparison to Shorea Robusta in Fragmented Dry Tropical Forest in West Bengal, India
}

\author{
Saroni Biswas \\ Department of Environmental Science, University of Kalyani \\ Kalyani 741235, West Bengal, India \\ Dilip K Khan (Corresponding author) \\ Department of Environmental Science, University of Kalyani \\ Kalyani 741235, West Bengal, India \\ Tel: 91-033-2580-8749Ｅ-mail: dilipkrkhan@gmail.com
}

Received: December 6, 2011 Accepted: December 10, 2011 Published: December 1, 2012

doi:10.5296/jee.v3i1.2327 URL: http://dx.doi.org/10.5296/jee.v3i1.2327

\begin{abstract}
The present study deals with the nutrient concentrations and its use by the dominant tree species of sal (Shorea robusta Roxb.) in comparison to one of the predominating tree species namely kendu (Diospyros melanoxylon Roxb.). The study was carried out in a highly encroached tropical dry deciduous forest known as Matha Protected Forest (MPF) of Purulia district, West Bengal, India. MPF is broadly fragmented into two parts viz. Plot A and Plot B. The main objective of the study is to define the distribution of major nutrient concentrations in green leaf, leaf litter and soil as well as the proficient use and resorption of nutrients by dominant plant species Shorea robusta Roxb. and one of the pre-dominant plant species Diospyros melanoxylon Roxb. To improve the understanding of flow of nutrients and their losses within the ecosystem, that will give information for effective forest management strategies. From analysis, it is depicted that nutrient use efficiency is in the order $\mathrm{P}>\mathrm{K}>\mathrm{N}$ for Shorea robusta Roxb. while the pattern is $\mathrm{K}>\mathrm{P}>\mathrm{N}$ in Diospyros melanoxylon Roxb. We found differences of nutrient concentration between the species and the variation in nutrient concentration depends on the site characteristics. Similarly variation in nutrient
\end{abstract}




\section{Macrothink}

Journal of Environment and Ecology ISSN 2157-6092 2012, Vol. 3, No. 1

remobilization also occurs. Above all, nutrient limitation occurs at the smaller fragmented Plot B, as Plot A shows decreased Nutrient Use Efficiency (NUE) and Nutrient Retranslocation Efficiency (NRE) than Plot B.

Keywords: Litterfall, Nutrient cycling, Nutrient use efficiency, Nutrient retranslocation efficiency

Abbreviations used: MPF- Matha Protected Forest, NUE- Nutrient Use Efficiency, NRENutrient Retranslocation Efficiency 


\section{Introduction}

Fragmentation of forests often leads to the habitat loss as well as species loss (Biswas and Khan, 2010; Gurd et al., 2001; Stefan-Dewenter et al., 2002). This directly or indirectly affect the functional aspect of the forests that is, mainly cause hindrance to nutrient dynamics. As the cycling of essential nutrients depends upon the soil and litterfall, when forests are destroyed, the vegetation in that particular area is also destroyed that provide the initiation of nutrient cycling, thus hampering the nutrient cycling (Biswas and Khan, 2011). Nutrients and energy transference from living biological components to the soil is closely related to litterfall and is the starting point for nutrient cycling (Gray and Schlesinger, 1981). Decomposition of litterfall which produces organic matter is an important factor for soil formation as well as nutrient cycling processes (van Wesemael, 1993). Therefore, tree nutrition, growth patterns and forest production is affected by litterfall (Newbould, 1967). Studies on nutrient content in litterfall give the functional state of the forest and can be used to improve forest management and production (Johansson, 1995; Robert et al., 1996). However, the index of nutrient use efficiency in litterfall can be used as an indicator of soil nutrient conditions (Xu et al., 2003). Litterfall constitutes (together with root turnover) a major portion of nutrient cycling between plants and soils, thus reflecting constraints on internal fluxes of C, N and P at ecosystem scale (Berg and Laskowski, 2006; Mc Groddy et al., 2004). In many cases, the seasonal variation of litterfall constitute an important aspect of nutrient cycling while the role of litter nutrients may be critical in tropical dry forests also (Campo et al., 2001). Primary production related to functioning of forests is influenced by the availability of nutrients that depends on the pattern and rate of nutrient cycling (Rawat and Singh, 1988). The litterfall in the forest floor acts as an input-output system of nutrients (Das and Ramakrishnan, 1985). The rate of forest litterfall and its gradual decay regulate energy flow, primary productivity and nutrient cycling in forest ecosystems (Waring and Schlesinger, 1985). It is particularly important in the nutrient budget of tropical forest ecosystems on nutrient-poor soils, where vegetation depends on recycling of nutrients contained in the plant detritus (Singh, 1968).

Functions of ecosystems in most of the tropical forests are constrained by lower rates of nutrient supply and water limitation (Tanner et al., 1998; Vitousek and Howarth, 1991). Nutrient limitation of growth is correlated with low concentrations of nutrient in leaves which indicate lower availability of that particular nutrient (Aerts and Chapin, 2000). Nutrient limitation plays an important role in plant growth that has been tested across developmental sequences in humid tropical ecosystems of Hawaii (Vitousek and Farrington, 1997). Several studies on litter dynamics in tropical forest ecosystems in India have been done (Biswas and Khan, 2011; Khiewtam and Ramakrishnan, 1993; Kumar and Deepu, 1992; Pandey et al., 2006; Rai and Proctor, 1986; Tripathi and Singh, 1995; Visalakshi, 1993). But information for tropical dry deciduous forest is limited due to certain constraints that prevail in the area. So a study is undertaken on nutrient use pattern in dry deciduous forest of Purulia district, West Bengal. The aim of this study is to assess the nutrients in different disturbed habitats considering soil, green leaves and leaf litter that can form a basis for shaping appropriate forest management strategies. 


\section{Materials and Method}

\subsection{The Site}

The study area, Matha Protected Forest (MPF) is situated between $23^{\circ} 05^{\prime} 00^{\prime \prime}$ to $23^{\circ} 12^{\prime} 30^{\prime \prime} \mathrm{N}$ latitude and $86^{\circ} 02^{\prime} 30^{\prime \prime}$ to $86^{\circ} 10^{\prime} 00^{\prime \prime}$ E longitude. MPF has two fragmented parts- A and B. The area is characterized by undulating topography with highest peak of $665 \mathrm{~m}$ in Plot A having better vegetative cover while Plot B is smaller with poor vegetative cover. Slope, relative relief, drainage density and road density ranges between $<2^{\circ}->9^{\circ}, 6.67-184.50 \mathrm{~m}$, $0.34-1.91 \mathrm{~km} / \mathrm{km}^{2}$ and $0.45-1.45 \mathrm{~km} / \mathrm{km}^{2}$ respectively. The climate is hot and dry with three distinct seasons viz. summer, monsoon and winter. Summer is intense and lasts from middle of March to mid of June. The monsoon starts from mid-June and lasts till end of September. Winter lasts from November to February. Minimum temperature fluctuates from $7^{\circ} \mathrm{C}$ to $14^{\circ} \mathrm{C}$ during months of December, January and February. Maximum temperature ranges from $42^{\circ} \mathrm{C}$ to $45^{\circ} \mathrm{C}$ during April to June. The average rainfall is $1031 \mathrm{~mm}$ while the highest rainfall $(1173 \mathrm{~mm})$ and lowest rainfall $(767 \mathrm{~mm})$ were recorded in the year 2000 and 1980 respectively. The south-west monsoon is the source of rainfall in Purulia. The soil in the area is laterite, red to brown in color and sandy loam in texture. The study area is covered with sal (Shorea robusta Roxb.) as a dominant species along with one of the predominating species kendu (Diospyros melanoxylon Roxb.).

\subsection{Vegetation Study and Soil Sampling}

Studies on vegetation were done through quadrat method (minimum size of quadrat for each sample plot was $20 \times 20 \mathrm{~m}$ and minimum number of quadrats was 5). Diameter at breast height (DBH) was measured. Biomass was estimated using the following regression equation (Brown et al., 1989).

$$
\mathrm{Y}=\exp \left\{-1.996+2.32^{*} \ln (\mathrm{D})\right\}
$$

Where $\mathrm{Y}=$ biomass per tree in $\mathrm{Kg}$ and $\mathrm{D}$ is the tree diameter at breast height $(\mathrm{cm})$.

Samples of soil were collected at five points randomly distributed in each plot at depths of 10 $-15 \mathrm{~cm}$. All of the soil samples were oven-dried at $70^{\circ} \mathrm{C}$, then grounded and passed through $2 \mathrm{~mm}$ sieve.

\subsection{Litterfall and Live Leaf Collection}

Litterfall was measured using five litter traps placed regularly within each plot (Xu et al., 2000), having $1 \mathrm{~m}^{2}$ area. Litterfall collection took place seasonally (in the month of March, July and November) for three consecutive years. Samples was washed thoroughly with water then air dried and finally oven dried at $60^{\circ} \mathrm{C}$ overnight, then milled for chemical analysis. Fresh mature leaves were collected from the crowns of Shorea robusta Roxb. and Diospyros melanoxylon Roxb. in the month of March, July and November for three consecutive years. These green leaves were processed in the same way as litterfall. 


\subsection{Nutrient Content}

Soil $\mathrm{pH}$ was measured by digital $\mathrm{pH}$-meter (Systronics-121, India) in a 1,5 (w,v) soil water suspension. Organic carbon was estimated by Walkley and Black method (1934). The samples of ground leaf litter and green leaf samples were digested with $\mathrm{HNO}_{3}-\mathrm{HClO}_{4}$ and analyzed for concentrations of P, K. Subsamples of soil were analyzed for available P following the molybdenum blue method of Jackson (1967), K was extracted from the soil in an ammonium acetate solution $(\mathrm{pH}=7)$ and measured with a digital flame photometer (Systronics-121, India). The total Kjeldahl nitrogen was determined by the micro-Kjeldahl procedure as described by Allen et al., 1974.

\subsection{Data Analysis}

The percent nutrient retranslocation efficiency (NRE) was calculated according to Finzi et al., 2001,

$$
\mathrm{NRE} \%=\{(\mathrm{A}-\mathrm{B}) / \mathrm{A}\} \times 100
$$

Where $\mathrm{A}$ is the nutrient in green leaves and B is the nutrient in leaf litter.

Nutrient use efficiency (NUE) was calculated according to Vitousek (1984),

$\mathrm{NUE}=$ litterfall mass $\left(\mathrm{g} \mathrm{m}^{-2}\right.$ year $\left.^{-1}\right) /$ nutrient content in litterfall $\left(\mathrm{g} \mathrm{m}^{-2}\right.$ year $\left.^{-1}\right)$.

After generating the data, statistical analysis was done using SPSS16.

\section{Results}

\subsection{Nutrient Characteristics of Forest Soil}

The Matha Protected Forest of Purulia comes under broad-leaved dry deciduous gregarious type of forest where sal (Shorea robusta Roxb.) is the dominant plant species with kendu (Diospyros melanoxylon Roxb.) as one of the predominant species at two fragmented plots (A and B) of the forest. Basically, the soil is acidic to neutral in nature which is the characteristic feature of lateritic soil. Nutrient characters of soil at two plots are given in Table 1. Soil organic carbon (SOC) [0.664 (0.037)] is higher at plot B compared to plot A [0.630 (0.006)]. $\mathrm{N} \%$ at $\mathrm{A}$ and $\mathrm{B}$ is $0.023(0.005)$ and $0.017(0.002)$ respectively. $\mathrm{C} / \mathrm{N}$ ratio is found to be 27 (in A) and 39 (in B) which reveals slower rates of decomposition and nutrient immobilization. In case of available $\mathrm{P}$, and exchangeable $\mathrm{K}$ the nutrient pattern in soil is similar at $99 \%$ level of significance ( $\mathrm{p}<0.001)$. From Table 1 it is found that SOC is negatively correlated with $\mathrm{N}$ as organic carbon is more than the available $\mathrm{N}$. The process of decomposition of litterfall decreases $\mathrm{N}$ availability as the carbon-nitrogen ratio of soil organic matter is related to the patterns of nitrogen immobilization and mineralization during organic matter decomposition by microorganisms and its value decreases as decomposition proceeds (Swift et al., 1979). Study by Tsutsumi (1987) indicates that the process is negatively correlated with the rate of nitrogen mineralization in decomposition experiments by soil incubation. 
Table 1. Site characteristic and soil properties for the sampling stands at Matha Protected Forest (MPF)

\begin{tabular}{llll}
\hline & Plot A & Plot B & t-test \\
\hline Altitude $(\mathrm{m})$ & 665 & 278 \\
Soil type & Red soil & Red soil & \\
Surface mineral soil properties $(10-15 \mathrm{~cm})$ & Mean $(\mathrm{SD})^{*}$ & Mean $(\mathrm{SD})^{*}$ & \\
Organic Carbon $(\%)$ & $0.630(0.006)$ & $0.664(0.037)$ & $*$ \\
Nitrogen $(\%)$ & $0.023(0.005)$ & $0.017(0.002)$ & $*$ \\
Available P $\left(\mathrm{mg} \mathrm{kg}^{-1}\right)$ & $14.992(0.385)$ & $14.261(0.563)$ & $*$ \\
Exchangeable K $\left(\mathrm{mg} \mathrm{kg}^{-1}\right)$ & $65.008(0.387)$ & $64.286(0.608)$ & $*$ \\
\hline
\end{tabular}

Levels of significance, ${ }^{*}, \mathrm{p}<0.001$

$(\mathrm{n}=15)$

* Standard deviation

\subsection{Nutrient Characteristics of Green Leaf}

Litterfall biomass of Shorea robusta Roxb. is almost highest about $1273 \mathrm{~g} \mathrm{~m}^{-2}$ year $^{-1}$ (average of two plots where plot A litterfall biomass is $1329 \mathrm{~g} \mathrm{~m}^{-2} \mathrm{year}^{-1}$ and plot B is $1218 \mathrm{~g} \mathrm{~m}^{-2}$ year ${ }^{-1}$ ), whereas it is $745 \mathrm{~g} \mathrm{~m}^{-2}$ year $^{-1}$ for Diospyros melanoxylon Roxb. (average of two plots where plot A litterfall biomass is $768.5 \mathrm{~g} \mathrm{~m}^{-2}$ year $^{-1}$ and plot B is $698 \mathrm{~g} \mathrm{~m}^{-2}$ year ${ }^{-1}$ ). There is a positive correlation (Figure 1) between the DBH (diameter at breast height) and AGB (above ground biomass) of both the species at two plots. Nutrient quality of green leaf is given in Table 2. N\% in Shorea robusta Roxb. is maximum followed by Diospyros melanoxylon Roxb. but $\mathrm{P}$ concentration of Diospyros melanoxylon Roxb. is significantly higher than Shorea robusta Roxb. whereas for $\mathrm{K}$ concentration, it is more for Shorea robusta Roxb. than Diospyros melanoxylon Roxb. But N, P and K concentrations of leaves are significantly higher in plot A than plot B. Therefore, the mineral component are site-dependent as well as between-species differences were found. 
Table 2. Mean nutrient concentrations with SD in green leaves of two species for Matha Protected Forest (MPF) in 3 year period from March 2007 to February 2010.

\begin{tabular}{lllllll}
\hline & \multicolumn{2}{l}{$\begin{array}{l}\text { Mean concentration } \\
\text { Shorea robusta }\end{array}$} & & \multicolumn{3}{l}{$\begin{array}{l}\text { Mean } \\
\text { Diospyros melanoxylon }\end{array}$} \\
\cline { 2 - 8 } & Plot A & Plot B & t-test & Plot A & Plot B & t-test \\
\hline $\mathrm{N}(\%)$ & 1.297 & 0.901 & $* *$ & 1.177 & 0.980 & $* *$ \\
& $(0.080)$ & $(0.078)$ & & $(0.045)$ & $(0.012)$ & \\
\hline $\mathrm{P}\left(\mathrm{mg} \mathrm{kg}^{-1}\right)$ & 215.283 & 203.940 & $* *$ & 281.862 & 277.387 & $* *$ \\
& $(5.467)$ & $(2.372)$ & & $(0.649)$ & $(0.773)$ & \\
\hline $\mathrm{K}\left(\mathrm{mg} \mathrm{kg}^{-1}\right)$ & 231.844 & 215.481 & $* *$ & 186.676 & 183.423 & $*$ \\
& $(2.707)$ & $(3.689)$ & & $(0.507)$ & $(1.228)$ & \\
\hline
\end{tabular}

Level of significance, ${ }^{*}, \mathrm{p}$ value $<0.01 ; * *, \mathrm{p}$ value $<0.001$ 2012, Vol. 3, No. 1

Table 3. Mean nutrient concentrations with SD in leaf litter of two species in Matha Protected Forest (MPF) in 3 year period from March 2007 to February 2010.

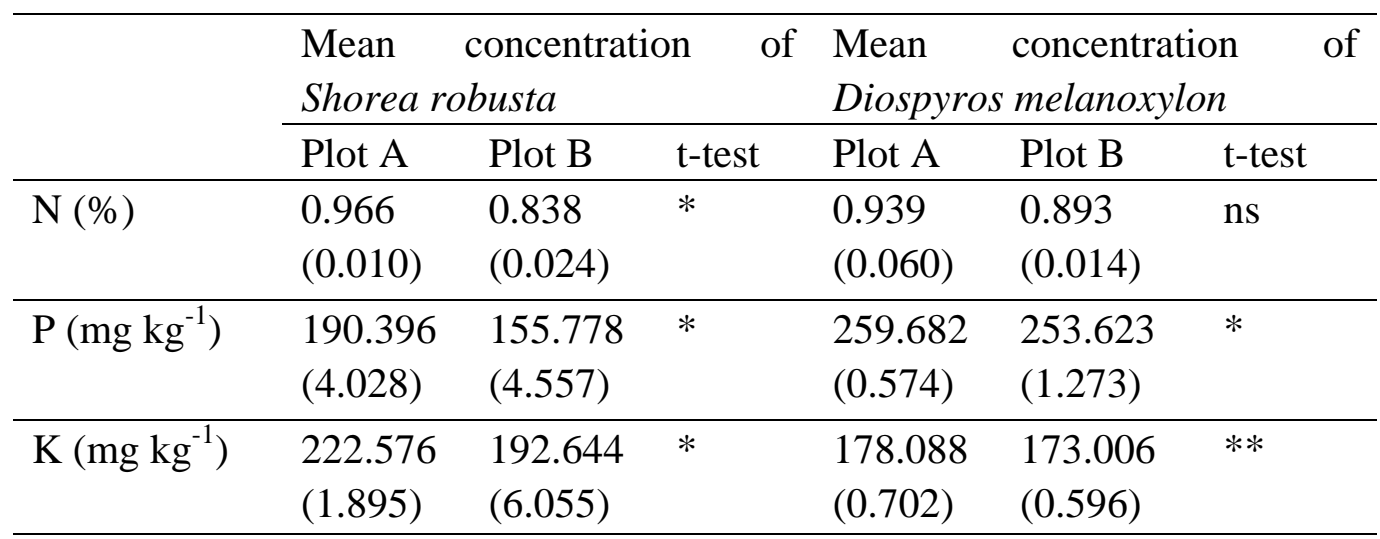

Level of significance, ${ }^{*}, \mathrm{p}<0.001 ; * *, \mathrm{p}<0.0001$; ns, non-significance 


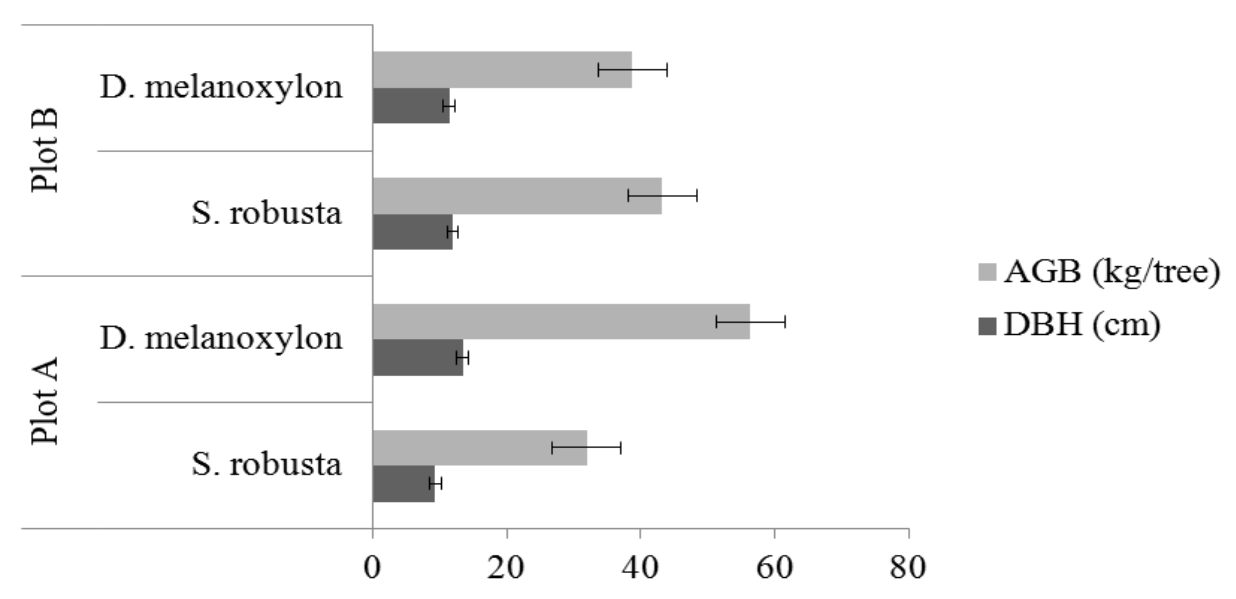

Figure 1. Diameter at Breast Height (DBH) and Above Ground Biomass (AGB) of two plant species at two plots of Matha Protected Forest (MPF)

AGB- Above Ground Biomass; DBH- Diameter at Breast Height

\subsection{Nutrient Quality of Litterfall}

Litter production mainly depends on the site fertility, but the other factors such as air temperature, soil water and nutrient availability also determine the production of litter (Jorgensen et al., 1975). The total litterfall amount was significantly affected by the regional features of the studied sites. The litterfall study was concentrated during three major period e.g. pre-monsoon, monsoon and post-monsoon and was strongly influenced by the high and low range of temperature and soil moisture. A pattern of litterfall in this study was broadly comparable to tropical deciduous forest of Mexico (Martinez-Yrizar and Sarukhan, 1990) and also comparable to the other predominating species in the tropical dry deciduous forest (Biswas and Khan 2011).

The total nutrient characteristics of the litterfall are summarized in Table 3 and the seasonal variations of major nutrient concentration in leaf litter is given in Figure 2. N concentration in Shorea robusta Roxb. leaf litter during monsoon is increased than compared to pre-monsoon and post-monsoon ( $\mathrm{p}<0.05$ at Plot A and $\mathrm{p}<0.01$ at Plot B). Same trend is found in Diospyros melanoxylon Roxb. except for Plot B $(\mathrm{p}<0.05)$. Likewise, seasonal variation is found for $\mathrm{P}$ concentration ( $\mathrm{p}<0.05$ at Plot $\mathrm{A}$ and $\mathrm{p}<0.01$ at Plot $\mathrm{B}$ ) in both the species. But seasonally $\mathrm{K}$ concentration in Shorea robusta Roxb. varies as $\mathrm{p}<0.05$ at Plot A and $\mathrm{p}<0.05$ at Plot B whereas it is $\mathrm{p}<0.01$ at Plot $\mathrm{A}$ and $\mathrm{p}<0.05$ at Plot B for Diospyros melanoxylon Roxb. For Shorea robusta Roxb. N (\%) in litterfall has recorded the highest value followed by Diospyros melanoxylon Roxb. For P, the pattern of concentration in two plant species is Diospyros melanoxylon Roxb. > Shorea robusta Roxb. But for K concentration in leaf litter, the pattern is different from that of P. Major nutrient pattern in two species at two plots are given in Figure 3. 
Shorea robusta
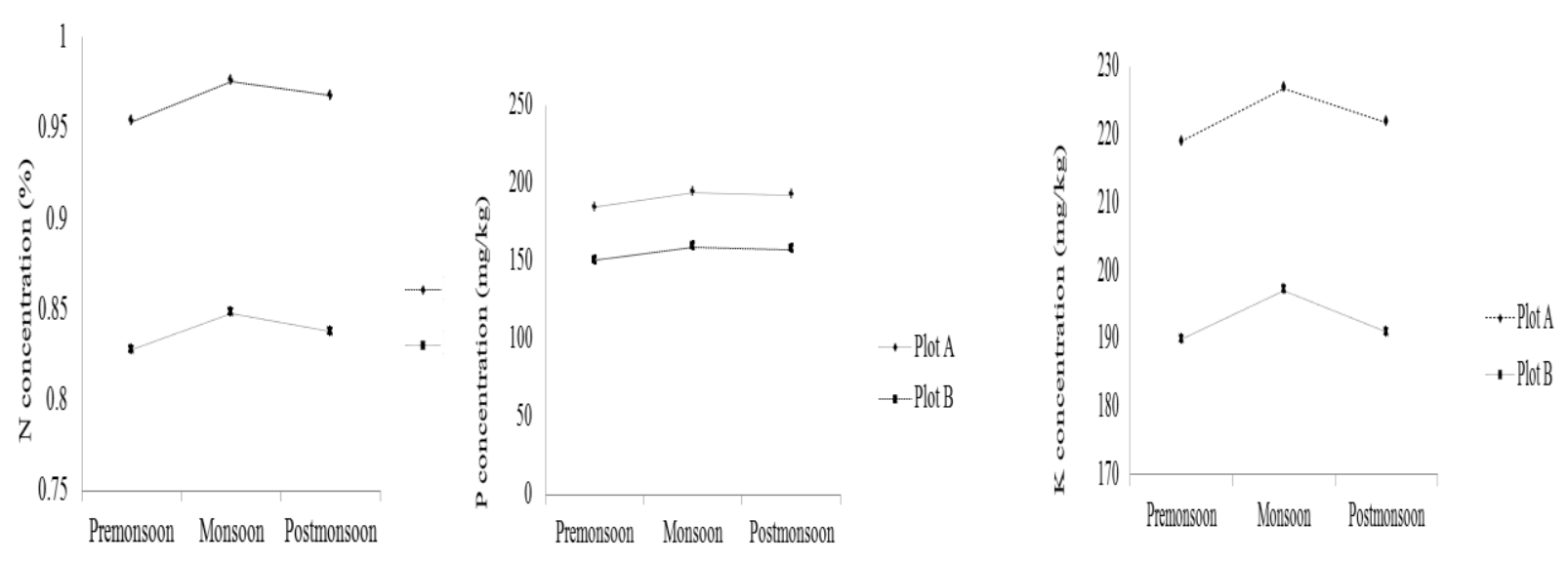

Diospyros melanoxylon
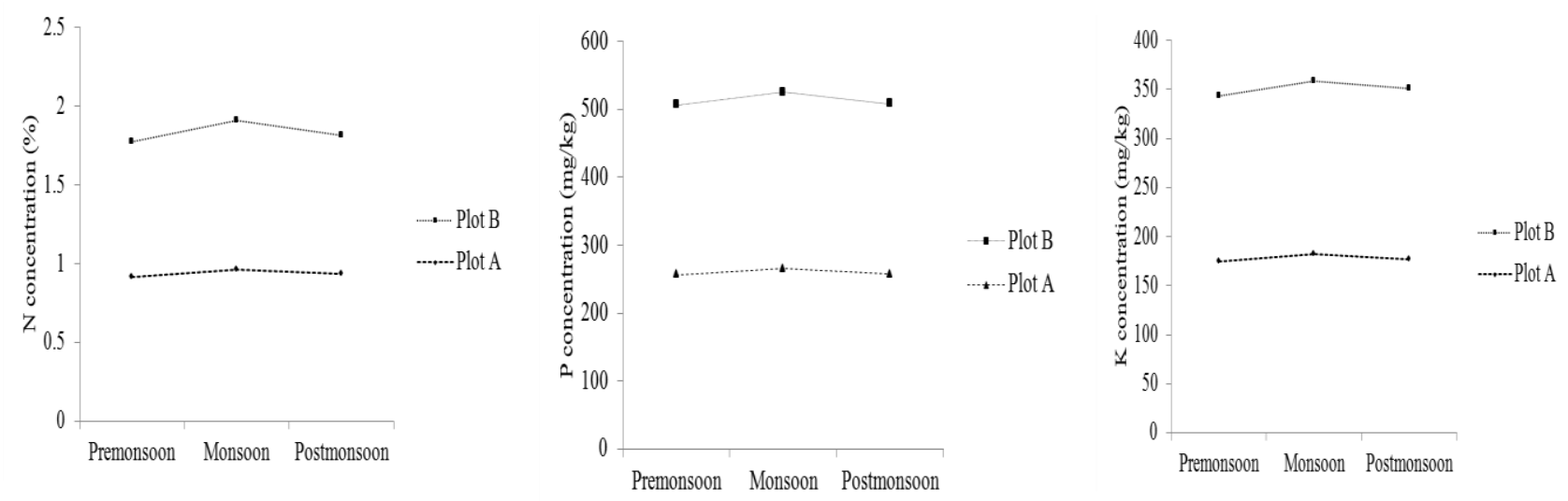

Figure 2. Seasonal variations in N, P and K concentrations of leaf litter in Matha Protected Forest in 3 year period from March 2007 to February 2011. 


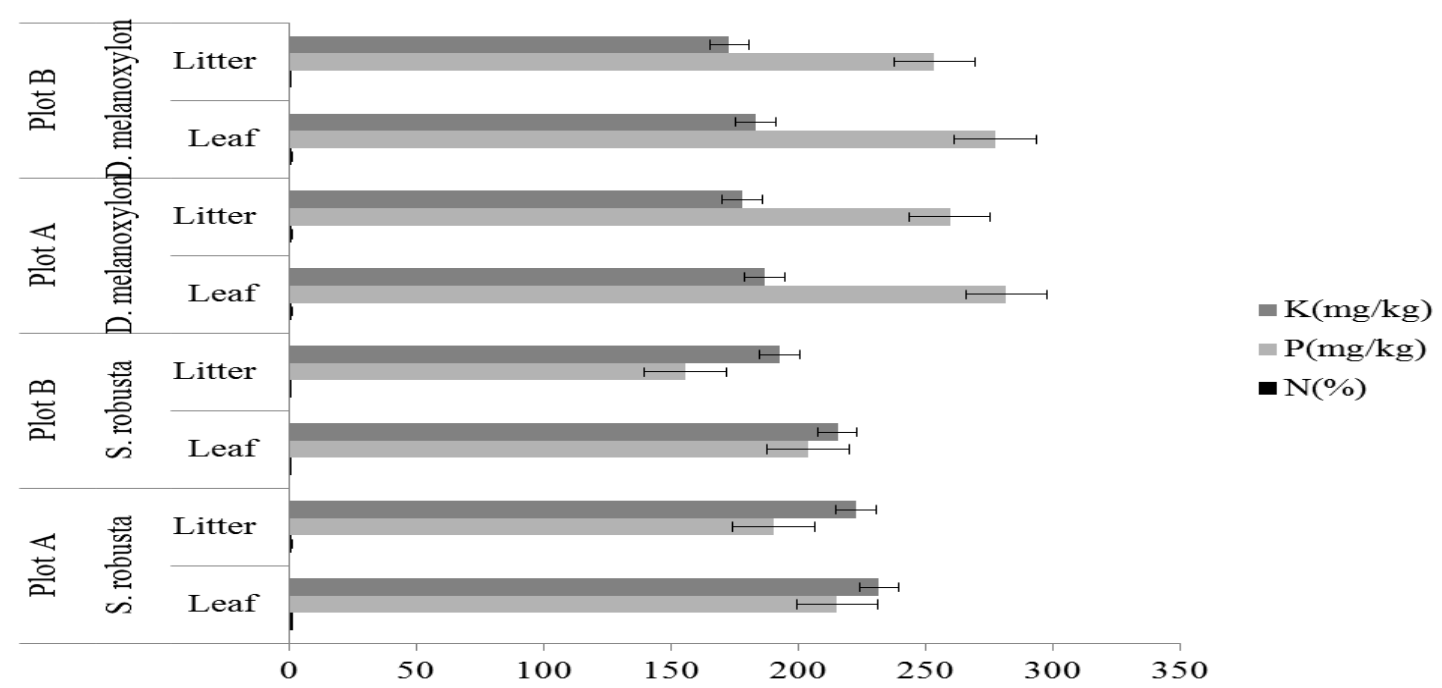

Figure 3. Major nutrient patterns in leaf and litter with standard error in Matha Protected Forest

\section{Discussions}

\subsection{Major Nutrient Use Efficiency}

Nutrient use efficiency (NUE) depends on the ability of efficient uptake of nutrients from soil. It also depends on transport, storage, mobilization, usage within the plant, and even on the environment. Efficient nutrient use is generally characterized by the lower nutrient concentration in the litterfall (Vitousek, 1984). In our study, the litterfall nutrient concentration is less than green leaf, therefore, NUE is increased. Dry mass / nutrient ratio of litterfall is an index of NUE, which has been used to calculate NUE. Nutrient use efficiency of dry deciduous forest of MPF is given in Table 4. In our experiment, $\mathrm{P}$ use efficiency for Shorea robusta Roxb. in both plots (A and B), is enhanced than N and $\mathrm{K}$ while for Diospyros melanoxylon Roxb., K use efficiency is increased followed by $\mathrm{P}$ and $\mathrm{N}$ (Figure 4). The forest stand has higher within stand efficiency of $\mathrm{P}$ and $\mathrm{K}$ at plot $\mathrm{B}$ than $\mathrm{A}$ (Table 4) which is related to lower availability of $\mathrm{P}$ and $\mathrm{K}$ at plot $\mathrm{B}$. This can be inferred that NUE in litterfall can be used as an indicator of soil nutrient availability (Vitousek, 1984; Lugo, 1992). But P and $\mathrm{K}$ use efficiency is decreased in evergreen broad-leaved forest ( $\mathrm{Xu}$ et al., 2003) and tropical rain forest (Vitousek, 1984) compared to our study. Nutrient use efficiency is higher at plot B. Likewise, P use efficiency of Shorea robusta Roxb. is greater than Diospyros melanoxylon Roxb. while N and K use efficiency of Shorea robusta Roxb. is lower than Diospyros melanoxylon Roxb. But the $\mathrm{N}$ use efficiency in both the plot for Diospyros melanoxylon Roxb. is lower than compared to another predominating species, piyal (Buchanania latifolia Roxb.) of tropical dry deciduous forest. Similarly, P and K use efficiency of Buchanania latifolia Roxb. is greater in plot B and lower in case of plot A in comparison to Diospyros melanoxylon Roxb. (Biswas and Khan, 2011). 


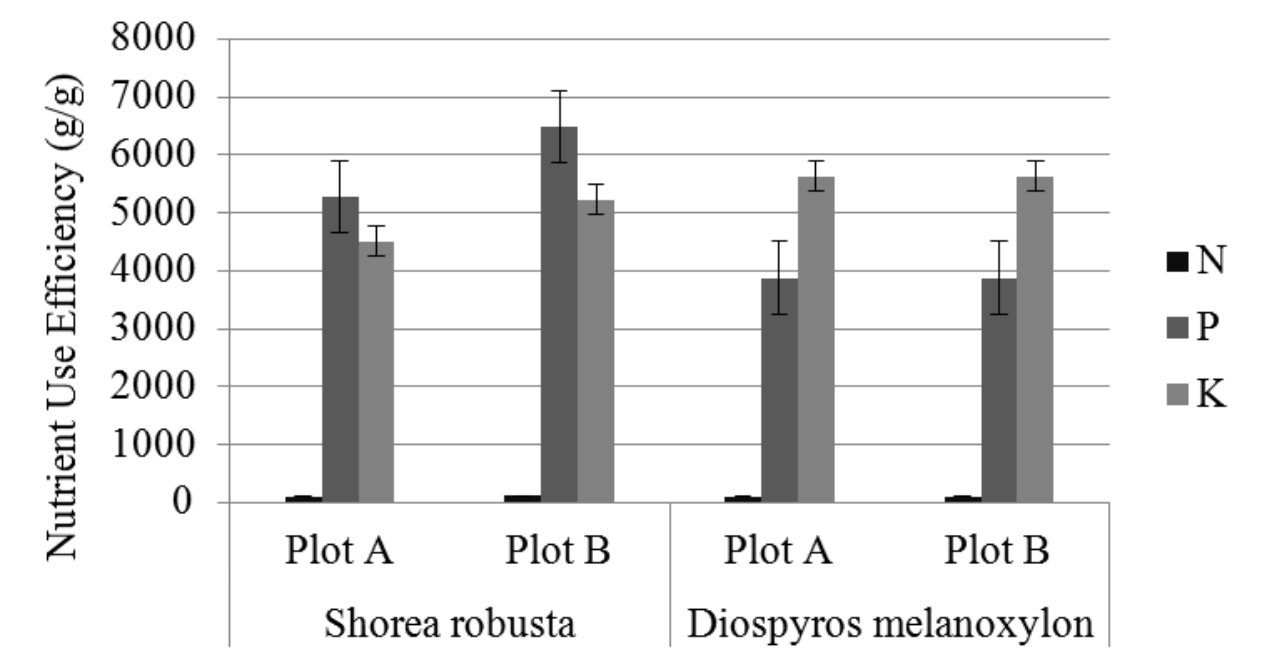

Figure 4. Nutrient Use Efficiency (NUE) of two species at two different blocks of Matha Protected Forest (MPF)

\subsection{Nutrient Dynamics and Retranslocation Efficiency}

The climax stage of any forest ecosystem has important characteristic of retranslocation efficiency mainly of essential nutrient (Prescott et al., 1989). Nutrient concentrations of leaf litter is significantly decreased than compared to green leaf (Table 2 and Table 3) throughout the forest and thus the nutrient retranslocation efficiency is high which suggests nutrient limitation. The translocation of $\mathrm{N}$ and $\mathrm{P}$ can provide the nutrients required for production of new leaves and allow independence from soil that provides an option for optimal management of the available elements in the forest ecosystem (Mellilo, 1981). The indices for retranslocation of nutrients in both the plots are given in Table 4. Throughout the forest $\mathrm{N}$ retranslocation efficiency is higher than that of $\mathrm{P}$ and $\mathrm{K}$, i.e. $\mathrm{N}$ is highly remobilized. Accordingly, within stands total NRE percent is 40 (Shorea robusta Roxb.) and 33 (Diospyros melanoxylon Roxb.) in plot A while it is 41 (Shorea robusta Roxb.) and 23 (Diospyros melanoxylon Roxb.) in plot B. But among the two plots, A shows decreased NRE than $\mathrm{B}$, suggesting improper nutrient transfer when nutrient concentration of soil, green leaves and leaf litters are considered.

The extent of retranslocation efficiency of $\mathrm{N}$ from the leaves in the present study is $9-20 \%$ in Diospyros melanoxylon Roxb. whereas it is significantly higher in Shorea robusta Roxb. of about $7-25 \%$. Correspondingly, the extent of retranslocation efficiency of $\mathrm{P}$ is $11-24 \%$ in Shorea robusta Roxb. and $8-9 \%$ in Diospyros melanoxylon Roxb. K retranslocation efficiency is $4-10 \%$ in Shorea robusta Roxb. that is considerably lower than in Diospyros melanoxylon Roxb. of about 5-6\% (vide Table 4 and Figure 5). The values are quite different than those reported for subtropical evergreen forest (Palma et al., 2000) and other predominating species Buchanania latifolia Roxb. at dry tropics (Biswas and Khan, 2011). Above all, we find between-species nutrient difference as well as site-dependent differences of nutrients at both plots of the forest. 
Table 4. Major nutrient use efficiency (NUE) and nutrient retranslocation efficiency (NRE) of two different species at two plots of Matha Protected Forest (MPF)

\begin{tabular}{lllllllll}
\hline Nutrients & \multicolumn{3}{l}{ Shorea robusta } & & \multicolumn{5}{l}{ Diospyros melanoxylon } \\
\cline { 2 - 10 } & Plot A & & Plot B & & Plot A & Plot B & \\
\cline { 2 - 10 } & NUE & NRE & NUE & NRE & NUE & NRE & NUE & NRE \\
& $\left(\mathrm{g} \mathrm{g}^{-1}\right)$ & $(\%)$ & $\left(\mathrm{g} \mathrm{g}^{-1}\right)$ & $(\%)$ & $\begin{array}{l}\left(\mathrm{g} \mathrm{g}^{-1}\right) \\
(\%)\end{array}$ & $\left(\mathrm{g} \mathrm{g}^{-1}\right)$ & $(\%)$ \\
\hline $\mathrm{N}$ & 103 & 25 & 119 & 7 & 106 & 20 & 112 & 9 \\
\hline $\mathrm{P}$ & 5274 & 11 & 6479 & 24 & 3874 & 8 & 3966 & 9 \\
\hline $\mathrm{K}$ & 4505 & 4 & 5227 & 10 & 5631 & 5 & 5817 & 6 \\
\hline
\end{tabular}

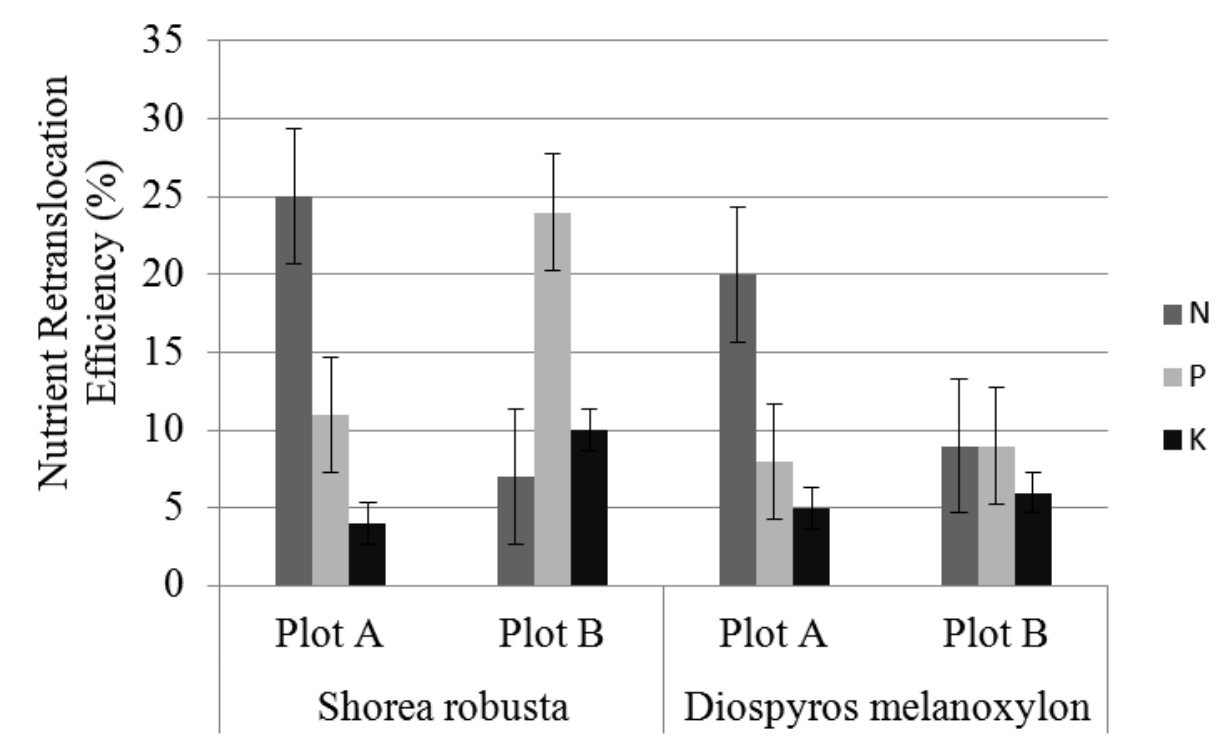

Figure 5. Nutrient Retranslocation Efficiency (NRE) of two species at two different blocks of Matha Protected Forest (MPF)

\section{Conclusion}

Matha Protected Forest is dry and a nutrient-poor ecosystem where the amount of nutrient retranslocation is very low that certainly retards the growth rate and development of plants. In our study, invariably higher leaf litter nutrient concentrations were observed during monsoon (rainy season). Peak period of leaf fall in these species occurs during winter season and new leaves appear on the onset of rainy season. Consequently, stored nutrients in the branches are transferred to the newly expanded foliage mass, which forms litter for rainy season and showed higher concentration of nutrients. This may be probable reason for higher nutrient concentration in leaf litter during rainy season. Apart from this, sometimes higher variations of nutrient concentrations in rainy season in the study area might be due to reflection of insect pest that cause premature leaf fall on the site during this period.

However, it is revealed from the study that $\mathrm{P}$ and $\mathrm{K}$ are more proficient in the stands. Therefore $\mathrm{P}$ and $\mathrm{K}$ constraint to primary production appears to be worth examining. Naturally the nutrient cycling in the forest is poor that reduces the growth and development of the 
plants mainly at smaller encroached fragmented plot B. Thus proper management of the forest is required for the survival of plant species and maintenance of biodiversity in the area.

\section{References}

Aerts, R., \& Chapin, F.S. (2000). The mineral nutrition of wild plants revisited, a re-evaluation of processes and patterns. Advances in Ecological Research, 30(1), 1-67. http://dx.doi.org/10.1016/S0065-2504(08)60016-1

Allen, S.E., Grimshaw, H.M., Parkinson, J.A., \& Quaramby, C. (1974). Chemical analysis of Ecological Materials. Blackwell Scientific Publications, Oxford.

Berg, B., \& Laskowski, R. (2006). Litter decomposition, A Guide to Carbon and Nutrient Turnover. Academic Press, San Diego.

Biswas, S., \& Khan, D.K. (2011). Major nutrient dynamics of two plant species at Matha Protected Forest of Purulia, West Bengal, India. International Journal of Environmental Science, 2(1), 60-65.

Biswas, S., Khan, D.K. (2010). Effect Of Habitat Fragmentation On Species Diversity At Matha Protected Forest Of Purulia, West Bengal, India. Proceedings of National Conference on Biotechnology and the Environment at National Institute of Technology, Durgapur. pp 138-144.

Brown, S., Gillespie A.J.R., \& Lugo, A.E. (1989). Biomass estimation methods for tropical forests with applications to forest inventory data. Forest Science, 35(4), 881-902.

Campo, J., Moass, M., Jaramillo, V.J., Martinez-Yrizar, A., \& Sarukhan, J. (2001). Phosphorous cycling in a Mexican tropical dry forest ecosystem. Biogeochemistry, 53(2), 161-179. [Online] Available: http://www.jstor.org/stable/1469442

Das, A.K., \& Ramakrishnan P.S. (1985). Litter dynamics in Khasi pine of northeast India. Forest Ecology and Management, 10(1-2), 135-153. http://dx.doi.org/10.1016/0378-1127(85)90018-0

Finzi, A.C., Allen, A.S., DeLucia, E.H., Ellsworth, D.S., \& Schlesinger, W.H. (2001). Forest litter production, chemistry and decomposition of following two years of free-air $\mathrm{CO}_{2}$ enrichment. Ecology, 82(2), 470-484. http://dx.doi.org/http://dx.doi.org/10.1890/0012-9658(2001)082[0470:FLPCAD]2.0.CO;2

Gray, J.T., \& Schlesinger, W.H. (1981). Nutrient cycling in Mediterranean Type Ecosystems. In, Miller PC (ed), Resource use by chaparral and matorral. A comparison of vegetation function in two Mediterranean Type Ecosystems, Ecological Studies, Springer-Verlag, New York, pp 259-286.

Gurd, D.B., Nudds, T.D., \& Rivard, D.H. (2001). Conservation of mammals in Eastern North American wildlife reserves, How small is too small? Conservation Biology, 15(5), 1355-1363. http://dx.doi.org/ 10.1111/j.1523-1739.2001.00188.x. 
Jackson, M.L. (1967). In, Soil Chemical Analysis. Prentice Hall, Englewood Cliffs NJ, pp 40-44.

Jaramillo, V.J., \& Sanford, R.L. (1995). Nutrient cycling in tropical deciduous forests. In, Bullock SH, Mooney HA, Medina E (eds), Seasonally Dry Tropical Forests. Cambridge University Press, Cambridge, 346-361.

Johansson, M.B. (1995). The chemical composition of needle and leaf litter from Scots pine, Norway spruce and White birch in Scandinavian forests. Forestry, 68(1), 49-62. http://dx.doi.org/ 10.1093/forestry/68.1.49

Jorgensen, J.R., Wells, C.G., \& Metz, L.J. (1975). The nutrient cycle. Key to continuous forest production. Journal of Forestry, 73(7), 400-403.

Khiewtam, R.S., \& Ramakrishnan, P.S. (1993). Litter and fine root dynamics of relic-sacred groove forest at Cherrapunji in northeastern India. Forest Ecology and Management, 60(3-4), 327-344. http://dx.doi.org/10.1016/0378-1127(93)90087-4

Kumar, B.M., \& Deepu, J.K. (1992). Litter production and decomposition dynamics in moist deciduous forests of the Western Ghats in Penninsular India. Forest Ecology and Management, 50(3-4), 181-201. http://dx.doi.org/10.1016/0378-1127(92)90335-7

Lugo, A.E. (1992). Comparision of tropical tree plantations with secondary forests of similar age. Ecological Monographs, 62(1), 1-41. http://dx.doi.org/http://dx.doi.org/10.2307/2937169

Martinez-Yrizar, A., \& Sarukhan, J. (1990). Litterfall patterns in a tropical deciduous forest in Mexico over a five-year period. Journal of Tropical Ecology, 6(4), 433-444. http://www.jstor.org/stable/2559193

Mc Groddy, M.E., DanFresne, T., \& Hedin, L.O. (2004). Scaling of C,N,P stoichiometry in forests worldwide, implications of terrestrial Redfield- type ratios. Ecology, 85(9), 2390-2401. http://dx.doi.org/http://dx.doi.org/10.1890/03-0351

Mellilo, J.M. (1981). Nitrogen cycling in deciduous forests. In Clark FE, Rosswall T (eds) Terrestrial Nitrogen Cycling, Ecological Bulletin (Stockholm), 33, 405-426.

Newbould, P.J. (1967). Methods for estimating the primary production of forests. IBP Handbook 2. Blackwell, Oxford.

Palma, R.M., Defrieri, R.L., Tortarolo, M.F., Prause, J., \& Gallardo, J.F. (2000). Seasonal changes of bioelements in the litter and their potential return to green leaves in four species of the Argentine subtropical forest. Annals of Botany, 85, 181-186. http://dx.doi.org/ 10.1006/anbo.1999.1005, http://www.idealibrary.com

Pandey, R.R., Sharma, G., Tripathi, S.K., \& Singh, A.K. (2006). Litterfall, litter decomposition and nutrient dynamics in a subtropical natural oak forest and managed plantation in northeastern India. Forest Ecology and Management, 240(1-3), 96-104. http://dx.doi.org/10.1016/j.foreco.2006.12.013 
Prescott, C.C., Corbin, J.P., \& Parkinson, D. (1989). Biomass, productivity and nutrient-use efficiency of aboveground vegetation in four Rocky Mountain coniferous forests. Canadian Journal of Forest Research, 19(3), 309-317. http://dx.doi.org/ 10.1139/x89-046

Rai, S.N., Proctor, J., \& Thompson, J. (1986). Ecological studies on fern rain forests in Karnataka, India.II. Litterfall. Journal of Ecology, 74, 455-463. [Online] Available: http://www.jstor.org/stable/2260266

Rawat, Y.S., \& Singh, J.S. (1988). Structure and function of oak forest in central Himalayas.II. Nutrient Dynamics. Annals of Botany, 62(4), 413-427.

Robert, B., Caritat, A., Bertoni, G., Vilar, L., \& Molinas, M. (1996). Nutrient content and seasonal fluctuations in the leaf component of coark-oak (Quercus suber L.) litterfall. Vegetatio, 122(1), 29-35. [Online] Available: http://www.jstor.org/stable/20048623

SadanandanNambiar, E.K., \& Fife, D.N. (1991). Nutrient retranslocation in temperate conifer. Tree Physiology, 9(1-2), 185-207. http://dx.doi.org/ 10.1093/treephys/9.1-2.185

Singh, K.P. (1968). Litter production and nutrient turnover in deciduous forest of Varanasi. In, Mishra R, Gopal B (eds). Proc Symp. Recent Advances in Tropical Ecology, Varanasi, India, pp 655-665.

Steffan-Dewenter, I., Munzenberg, U., Burger, C., Thies, C., \& Tscharntke, T. (2002). Scale dependent effects of landscape context on three pollinator guilds. Ecology, 83(5), 1421-1432. http://dx.doi.org/ 10.1093/treephys/9.1-2.185

Swift, M.J., Heal, O.W., \& Anderson, J.M. (1979). Decomposition in Terrestrial Ecosystems. Studies in Ecology Volume 5, University of California Press, Berkeley, C.A.

Tanner, E.V.J., Vitousek, P.M., \& Cuevas, E. (1998). Experimental investigation of nutrient limitation of forest growth on wet tropical mountains. Ecology, 79(1), 10-22. http://dx.doi.org/10.1890/0012-9658(1998)079[0010:EIONLO]2.0.CO;2

Tripathi, S.K., \& Singh, K.P. (1995). Litter dynamics of recently harvested and mature bamboo savannahs in a dry tropical region in India. Journal of Tropical Ecology, 11(3), 403417. [Online] Available: http://www.jstor.org/stable/2560222

Tsutsumi, T. (1987). The nitrogen cycle in a forest. Memoirs of College Agriculture, Kyoto University, 130, 1-16

vanWesemael, B. (1993). Litter decomposition and nutrient distribution in humus profiles in some Mediterranean forests in Southern Tuscany. Forest Ecology and Management, 57(1-4), 99-114. http://dx.doi.org/10.1016/0378-1127(93)90165-J

Visalakshi, N. (1993). Litterfall, standing crop of litter and their nutrients in two tropical dry evergreen forests in India. International Journal of Ecology and Environmental Sciences, 19(3), 163-180. 
Vitousek, P.M., \& Farrington, H. (1997). Nutrient limitation and soil development, experimental tests of a biogeochemical theory. Biogeochemistry, 37, 63-75. http://dx.doi.org/ 10.1023/A:1005757218475

Vitousek, P.M., \& Howarth, R.W. (1991). Nitrogen limitation on land and the sea, how can it occur? Biogeochemistry, 13(2), 87-115. http://dx.doi.org/ 10.1007/BF00002772

Vitousek, P.M. (1984). Litterfall, nutrient cycling, and nutrient limitation in tropical forests. Ecology, 65(1), 285-298. http://dx.doi.org/10.2307/1939481

Walkley, A., \& Black, I.A. (1934). An examination of the Degtjareff method for determining organic carbon in soils, Effect of variations in digestion conditions and of inorganic soil constituents. Soil Science, 63, 251-263.

Waring, R.H., \& Schlesinger, W.H. (1985). Forest Ecosystem, Concepts and Management. Academic Press, New York, pp 181-211.

Whittaker, R.H., Likens, G.E., Bormann, F.H., \& Siccama, T.G. (1979). The Hubbard Brook study, nutrient cycling and element behavior. Ecology, 60(1), 203-220. [Online] Available: http://www.jstor.org/stable/1936481

Xu, X., Enoki, T., Hirata, E., \& Tokashiki, Y. (2003). Pattern and chemical composition of fine litterfall in a subtropical forest in northern Okinawa Island, Japan. Basic and Applied Ecology, 4(3), 229-237. http://dx.doi.org/10.1078/1439-1791-00149

Xu, X.N., Tokashiki, Y., Hirrata, E., Enoki, T., \& Nogami, K. (2000). Ecological studies on subtropical evergreen broad-leaved forest in Okinawa, Japan, Litter production and nutrient input. Journal of Forest Research, 5, 151-156. http://dx.doi.org/ 10.1007/BF02762394 